\title{
Histomorphometric and Immunohistochemical Analysis in the Uterus of Rats Treated with Genistein or Estrogen Immediately or Later After Castration
}

\author{
Carbonel A.A.F ${ }^{1}$, Simões R.S ${ }^{2}$, GIRÃO J.H.R.C ${ }^{1}$, Reis L.A ${ }^{3}$, Maganhin C.C ${ }^{1,}$ Baracat E.C ${ }^{2}$,
} Simões M.J' ${ }^{1}$, Soares Jr J.M ${ }^{2}$

1-Department of Morphology and Genetics, Federal University of São Paulo, UNIFESP - Brazil

2-Department of Obstetrics and Gynecology, University of São Paulo, USP-Brazil

3- Department of Nephrology, Federal University of São Paulo, UNIFESP - Brazil

This study used histomorphometric and immunohistochemical analysis to investigate the effect of genistein or estrogen in the uterus of rats treated immediately or later after castration. Methods: Were used 60 adult castrated rats divided into six groups: GI = received vehicle (propylene glycol); immediately after castration; GII = received genistein immediately after castration; GIII = received genistein 30 days after castration; GIV = received only the vehicle after 30 days of castration; GV = received 17 $\beta$-estradiol immediately after castration; GVI = received $17 \beta$-estradiol after 30 days of castration. Drugs were administered by gavage $(0.5 \mathrm{ml})$ for 30 consecutive days, and after the last administration, the animals were anesthetized and the uteri were removed immediately immersed in $10 \%$ formaldehyde for subsequent histological processing in paraffin for morphological and immunohistochemical studies of Ki67 and Vegf-A. Statistical analyses were performed using the software GraphPadPrism $^{\circledR} 5.0$ (GraphPad Software Inc.) $(\mathrm{p}<0.05)$. Results: The morphological and morphometric data showed a more developed endometrium in groups treated lately with estrogen or genistein than when treated immediately after oophorectomy (GVI $>$ GV $>$ GIV). We noticed a higher percentage of cell proliferation (Ki-67) (Fig 1) in groups where the initiation of treatment with either estradiol or genistein was delayed. The same was noticed as to the reactivity of Vegf-A $(\mathrm{GVI}>\mathrm{GV}>\mathrm{GIV}=\mathrm{GIII}>\mathrm{GII}=\mathrm{GI})$ (fig 2). Conclusion: Late estrogen treatment after cessation of gonad function in rats induces a more intense cell proliferation especially the than ones of early treatment. The proliferative response to genistein treatment is less intense than estrogen one.

\section{References:}

Francisco AM, Carbonel AF, Simões RS, Soares JM Jr, Baracat EC, Haidar MA. Do extracts of oral soybean augment the trophic effect of estrogen on the ratuterus? Climacteric. 2013 Feb;16(1):161-8.

Carbonel AA, Simões RS, Santos RH, Baracat MC, Simões Mde J, Baracat EC, Soares Júnior JM. Effects of high-dose isoflavones on rat uterus. Rev Assoc Med Bras. 2011 Sep-Oct;57(5):534-9.

Financial Support by FAPESP 2010/11900-4 and 2010/11898-0 


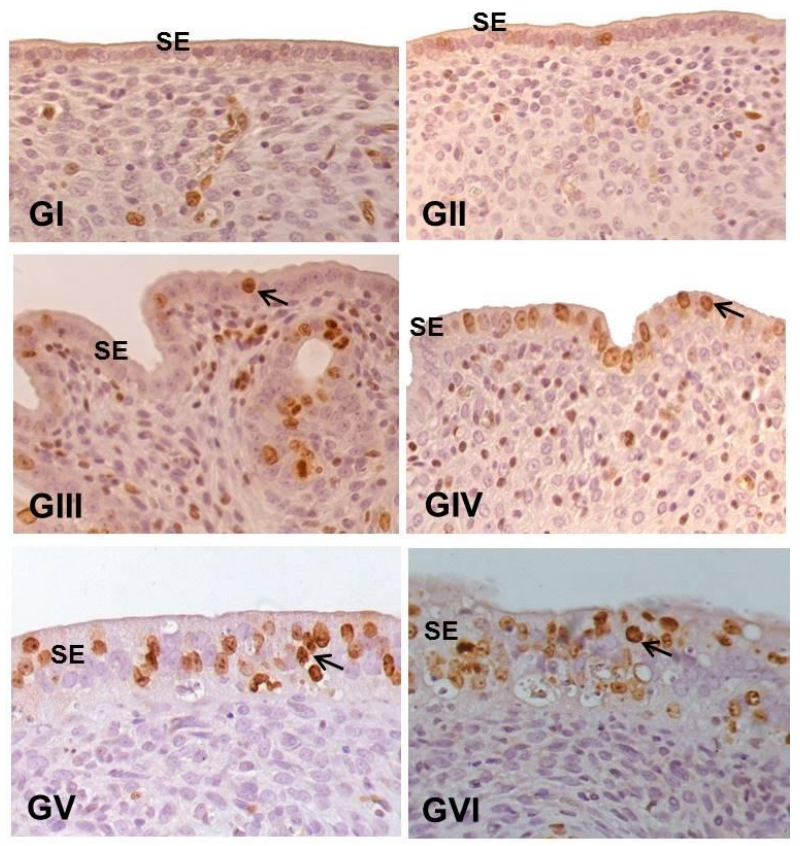

Figure 2 - Photomicrographs of uterine segments immunohistochemically reactive to Ki67 and originating from rats in the different study groups. Note surface epithelium (SE) with clusters of proliferating cells in the groups treated late (GIV and GVI) compared to groups treated immediately after ovariectomy (GIII and GV) (arrows). (400X)

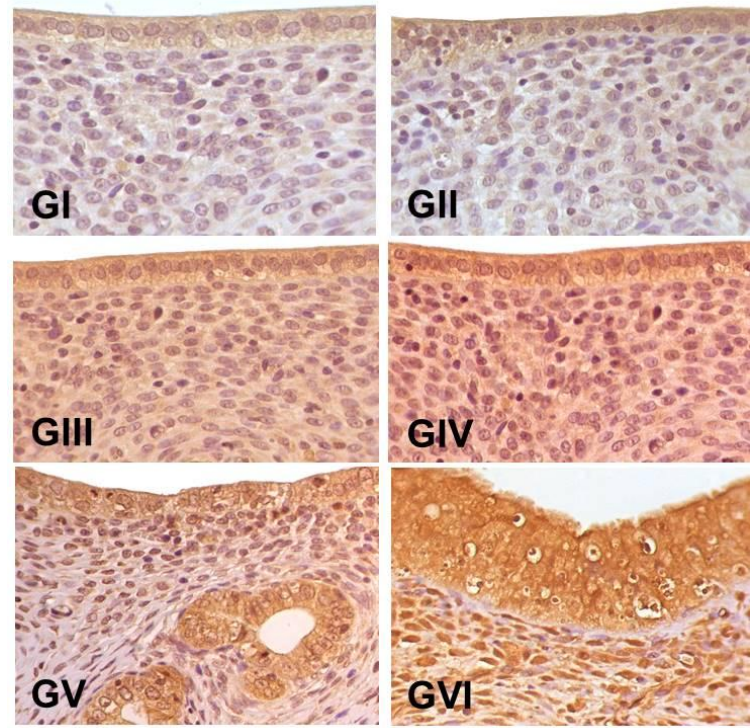

Figure 3 - Photomicrographs of uterine sections subjected to immunohistochemistry for the detection of VEGF-A, in rats of the different study groups. (400X). 